\title{
Surgical Treatment of Peri-Implantitis: Literature Review
}

\author{
Matías Bellolio* \\ Dentist, University of the Andes, Private Practice, Santiago, Chile
}

*Corresponding author: Matías Bellolio, Dentist, University of the Andes, Private Practice, Santiago, Chile, Tel: +56962646844 ; E-mail: matiasbellolio@gmail.com

Received: 27 Jan, 2018 | Accepted: 31 Jan, 2018 | Published: 08 Feb, 2018

Citation: Bellolio M (2018) Surgical Treatment of PeriImplantitis: Literature Review. Int J Dent Oral Health 4(1): dx.doi. org/10.16966/2378-7090.248

Copyright: () 2018 Bellolio M. This is an open-access article distributed under the terms of the Creative Commons Attribution License, which permits unrestricted use, distribution, and reproduction in any medium, provided the original author and source are credited.

\section{Abstract}

Objective: The objective of this study was to describe in a narrative review, the efficacy and indications of surgical therapy in the treatment of peri-implantitis.

Method: A narrative review was conducted through a literature search in the following electronic databases: PubMed, EBSCO, Cochrane, Google Scholar, as well as a manual search of the articles published in the "Journal of Periodontology" for availability in our library, and the literature cited in the selected studies. To develop the theoretical framework was used as support material in the area of periodontics books. Electronic search for the following key words were used: "periimplantitis", "therapy", "treatment", "SURGERY" and "SURGICAL PROCEDURES, OPERATIVE" and the Boolean operators $A N D$ and OR. To analyze the risk of bias in clinical trials bias the tone for the Cochrane Collaboration for reviews of interventions used.

Results: A total of 6,167 articles were cast, of which 343 were potentially relevant articles. Of these, 256 were dismissed for not meeting the inclusion and exclusion criteria; and 65 did not answer the research question. Finally reduced to a total of 22 articles were included in this review.

Conclusion: More clinical evidence is needed in the scientific literature to determine the efficacy and indications of surgical treatment for the treatment of peri-implantitis.

Glossary: BMP: Bone Morphogenetic Protein; BOP: Bleeding on Probing; CA: Access Surgery; EMBC: Center For Evidence Based Medicine at The University of Oxford; CHX: Chlorhexidine; CPC: Cetyl Pyridinium Chloride; CR: Surgical Resection; EDTA: Etildiaminotetraacético Acid; $\mathrm{H}$ : Men; $\mathrm{H}_{2} \mathrm{O}_{2}$ : Hydrogen Peroxide; IOI: Implant Osseointegrated; ITO Graft Bone Tissue; Laser $\mathrm{CO}_{2}$ : Carbon Dioxide Laser; Er: YAG: Erbium: Yttrium-Aluminum-Garnet; M: Women; Nacl: Physiological Saline; NHA: Hydroxyapatite Nanocrystals; NIC: Clinical Attachment Level; NR: Not Reported; PD / PS: Probing Depth; ROG: Guided Bone Regeneration.

\section{Introduction}

Dental implants have been used successfully in partial and total edentulous patients; however, the rise in installation also correlates to an increase in peri-implant disease.

The peri-implantitis is defined as inflammation of the mucosa surrounding the implant, accompanied by loss of supporting tissues. As for treatment, the first thing is to treat risk factors, such as periodontal disease throughout, then start therapy of peri-implantitis [1].

Although, initially, it was thought that the treatment would as with other periodontal diseases, it has been found that both its etiology and pathogenesis are different, therefore, their treatment must also be different.

The objectives of treatment are directed to the removal of the etiological factors; eliminate inflammation of soft tissues and disinfection of the implant and regeneration of the lost bone tissue. Despite this, it has been seen that the non-surgical treatment is not sufficient to resolve pathology, being necessary to add the surgical therapy for the treatment of peri-implantitis. It is at this point that there is no general consensus on the efficacy and indications on the implementation of this treatment.

The objective of this narrative review is to answer the following research question: What is the efficacy and indications of surgical treatment of peri-implantitis?

\section{Objectives}

\section{General objective}

The overall objective of this study is to describe a narrative review, the efficacy and indications of surgical therapy in the treatment of peri-implantitis.

\section{Specific objectives}

- Describe the peri-implantitis.

- Describe the surgical treatment of peri-implantitis and the techniques currently used.

- Describe the efficacy of surgical therapy for the treatment of peri-implantitis, by evaluating periodontal parameters.

- Describe the indications for surgical therapy for the treatment of peri-implantitis. 


\section{Method}

A narrative review was conducted through a literature search in the following electronic databases: PubMed, EBSCO, Cochrane, Google Scholar, as well as a manual search of the articles published in the "Journal of Periodontology" available on our library, and the literature cited in the selected studies. To develop the theoretical framework utilizaronlibros the area of periodontics as support materials.

Electronic search for the following key words were used: "periimplantitis", "therapy", "treatment", "SURGERY" and "SURGICAL PROCEDURES, OPERATIVE" and the Boolean operators AND and OR.

Publications written in English and Spanish, published from 2005 onwards, which have completed their studies in humans and were available in full-text journals and databases subscribed by the central library "José Enrique Diez" of were selected Universidad de los Andes. RCTs were selected; nonrandomized trials; systematic reviews; Case-control studies, descriptive, and case reports, only human. On the other hand, expert opinions and letters to the editor excluded. The level of scientific evidence of the studies was performed using the following proposal made by the Centre for Evidence-Based Medicine (EMBC) Oxford [2].

\section{Level of Evidence Type of Study (Table 1)}

1a. Systematic review of randomized clinical trials, with homogeneity

1b. Randomized controlled trial with narrow confidence interval.

1c. Clinic Practice (“all or none") $\left(^{*}\right)$

The 2nd systematic review of cohort studies, with homogeneity.

2b. Study cohort or randomized clinical trial of low quality $(* *)$.

2c. Outcomes Research (***), ecological studies.

3a. Systematic review of case-control studies, with homogeneity.

3b. Study of cases and controls.

4. Case series or cohort and case-control studies of low quality $\left({ }^{* * * *}\right)$.

5. Expert opinion without explicit critical appraisal, or based on physiology, bench research or first principles ${ }^{* * * * *}$ ).

Grade of Recommendation Level of Evidence (Table 2)
A. Level 1 Survey.
B. 2-3 level studies, or extrapolation of level 1 study.
C. Studies Level 4, or extrapolation from studies of level 2-3.
D. Studies Level 5, or inconclusive studies of any level.

The extrapolation applies when our clinical scenario has important differences from the original study situation.

\section{Meaning Degrees Recommendation (Table 3)}
A. Strongly recommended
B. Recommendation pro
C. Recommendation friendly but inconclusive.
D. Not recommended or disapprove.

The quality evaluation was performed by reporting the following guidelines

- Questionnaire CONSORT for RCTs [3].

- TREND Questionnaire for non-randomized clinical trials [4].

- STROBE for observational studies [5].

The risk of bias was estimated for each selected randomized clinical trial based on the standard for review of The Cochrane Collaboration bias with a score of 1 to 3 in the following cases: (Table 4)

1) Low risk (when all the criteria are met)

2) Moderate risk (when one or more criteria were partly met)

3) High risk of bias (when one or more criteria are not met) [6].

The ethical aspect was evaluated by analyzing the studies themselves, where it was established whether these works were approved by ethics committees, whether they have signed informed consent of patients, or if not mention this aspect.

The search results are organized into tables, in the following order:

- Author

- Year

- Number of patients (n)

- Sex (F / M)

- Average age (years)

- Smoking (Yes / No)

- Follow-up (months)

- Implants (n)

- Implant surface

- Sack depth (mm)

- Antibiotics (Yes / No)

- Surgical intervention aids

- Using membrane (Yes / No)

- PS reduction ( $\mathrm{mm}$ or \%)

- Bone gain (mm)

- Gain NIC (mm or \%) 
Table 1: Oxford Centre for Evidence-based Medicine - Levels of Evidence (March 2009).

\begin{tabular}{|c|c|c|c|c|c|}
\hline Level & $\begin{array}{c}\text { Therapy / } \\
\text { Prevention, } \\
\text { Aetiology / Harm }\end{array}$ & Prognosis & Diagnosis & $\begin{array}{c}\text { Differential diagnosis } \\
\text { / symptom prevalence } \\
\text { study }\end{array}$ & Economic and decision analyses \\
\hline $1 \mathrm{a}$ & $\begin{array}{l}\text { SR (with } \\
\text { homogeneity }^{*} \text { ) of } \\
\text { RCTs }\end{array}$ & $\begin{array}{l}\text { SR (with homogeneity*) } \\
\text { of inception cohort } \\
\text { studies; CDR" } \\
\text { validated in different } \\
\text { populations }\end{array}$ & $\begin{array}{l}\text { SR (with homogeneity*) of } \\
\text { Level } 1 \text { diagnostic studies; } \\
\text { CDR" with } 1 \text { b studies } \\
\text { from different clinical } \\
\text { centres }\end{array}$ & $\begin{array}{l}\text { SR (with homogeneity*) } \\
\text { of prospective cohort } \\
\text { studies }\end{array}$ & $\begin{array}{l}\text { SR (with homogeneity*) of Level } 1 \\
\text { economic studies }\end{array}$ \\
\hline $1 \mathrm{~b}$ & $\begin{array}{l}\text { Individual RCT } \\
\text { (with narrow } \\
\text { Confidence } \\
\text { Interval"i) }\end{array}$ & $\begin{array}{l}\text { Individual inception } \\
\text { cohort study with > } \\
80 \% \text { follow-up; CDR" } \\
\text { validated in a single } \\
\text { population }\end{array}$ & $\begin{array}{l}\text { Validating }{ }^{* *} \text { cohort study } \\
\text { with good" " " reference } \\
\text { standards; or CDR" tested } \\
\text { within one clinical centre }\end{array}$ & $\begin{array}{l}\text { Prospective cohort } \\
\text { study with good follow- } \\
\text { up }^{\star \star \star \star}\end{array}$ & $\begin{array}{l}\text { Analysis based on clinically sensible } \\
\text { costs or alternatives; systematic } \\
\text { review(s) of the evidence; and } \\
\text { including multi-way sensitivity } \\
\text { analyses }\end{array}$ \\
\hline 1c & All or none§ & All or none case-series & $\begin{array}{l}\text { Absolute SpPins and } \\
\text { SnNouts" “" }\end{array}$ & All or none case-series & $\begin{array}{l}\text { Absolute better-value or worse-value } \\
\text { analyses " " " }\end{array}$ \\
\hline $2 a$ & $\begin{array}{l}\text { SR (with } \\
\text { homogeneity }^{*} \text { ) of } \\
\text { cohort studies }\end{array}$ & $\begin{array}{l}\text { SR (with homogeneity*) } \\
\text { of either retrospective } \\
\text { cohort studies or } \\
\text { untreated control } \\
\text { groups in RCTs }\end{array}$ & $\begin{array}{l}\text { SR (with homogeneity }{ }^{*} \text { ) } \\
\text { of Level >2 diagnostic } \\
\text { studies }\end{array}$ & $\begin{array}{l}\text { SR (with homogeneity }{ }^{*} \text { ) } \\
\text { of } 2 \mathrm{~b} \text { and better studies }\end{array}$ & $\begin{array}{l}\text { SR (with homogeneity*) of Level >2 } \\
\text { economic studies }\end{array}$ \\
\hline $2 b$ & $\begin{array}{l}\text { Individual cohort } \\
\text { study (including } \\
\text { low quality RCT; } \\
\text { e.g., <80\% follow- } \\
\text { up) }\end{array}$ & $\begin{array}{l}\text { Retrospective cohort } \\
\text { study or follow-up } \\
\text { of untreated control } \\
\text { patients in an RCT; } \\
\text { Derivation of CDR" } \\
\text { or validated on split- } \\
\text { sample§§§ only }\end{array}$ & $\begin{array}{l}\text { Exploratory ** cohort study } \\
\text { with good" " " reference } \\
\text { standards; CDR" after } \\
\text { derivation, or validated } \\
\text { only on split-sample§§§ or } \\
\text { databases }\end{array}$ & $\begin{array}{l}\text { Retrospective cohort } \\
\text { study, or poor follow-up }\end{array}$ & $\begin{array}{l}\text { Analysis based on clinically sensible } \\
\text { costs or alternatives; limited review(s) } \\
\text { of the evidence, or single studies; } \\
\text { and including multi-way sensitivity } \\
\text { analyses }\end{array}$ \\
\hline 2c & $\begin{array}{l}\text { "Outcomes" } \\
\text { Research; } \\
\text { Ecological studies }\end{array}$ & "Outcomes" Research & & Ecological studies & Audit or outcomes research \\
\hline $3 a$ & $\begin{array}{l}\text { SR (with } \\
\text { homogeneity*) } \\
\text { of case-control } \\
\text { studies }\end{array}$ & & $\begin{array}{l}\text { SR (with homogeneity*) of } \\
\text { 3b and better studies }\end{array}$ & $\begin{array}{l}\text { SR (with homogeneity*) } \\
\text { of } 3 \mathrm{~b} \text { and better studies }\end{array}$ & $\begin{array}{l}\text { SR (with homogeneity }{ }^{*} \text { ) of } 3 b \text { and } \\
\text { better studies }\end{array}$ \\
\hline $3 b$ & $\begin{array}{l}\text { Individual Case- } \\
\text { Control Study }\end{array}$ & & $\begin{array}{l}\text { Non-consecutive study; } \\
\text { or without consistently } \\
\text { applied reference } \\
\text { standards }\end{array}$ & $\begin{array}{l}\text { Non-consecutive } \\
\text { cohort study, or very } \\
\text { limited population }\end{array}$ & $\begin{array}{l}\text { Analysis based on limited alternatives } \\
\text { or costs, poor quality estimates } \\
\text { of data, but including sensitivity } \\
\text { analyses incorporating clinically } \\
\text { sensible variations. }\end{array}$ \\
\hline 4 & $\begin{array}{l}\text { Case-series } \\
\text { (and poor quality } \\
\text { cohort and case- } \\
\text { control studies§§) }\end{array}$ & $\begin{array}{l}\text { Case-series (and poor } \\
\text { quality prognostic } \\
\text { cohort studies }^{* * *} \text { ) }\end{array}$ & $\begin{array}{l}\text { Case-control study, poor } \\
\text { or non-independent } \\
\text { reference standard }\end{array}$ & $\begin{array}{l}\text { Case-series or } \\
\text { superseded reference } \\
\text { standards }\end{array}$ & Analysis with no sensitivity analysis \\
\hline 5 & $\begin{array}{l}\text { Expert opinion } \\
\text { without explicit } \\
\text { critical appraisal, } \\
\text { or based on } \\
\text { physiology, bench } \\
\text { research or "first } \\
\text { principles" }\end{array}$ & $\begin{array}{l}\text { Expert opinion } \\
\text { without explicit critical } \\
\text { appraisal, or based } \\
\text { on physiology, bench } \\
\text { research or "first } \\
\text { principles" }\end{array}$ & $\begin{array}{l}\text { Expert opinion without } \\
\text { explicit critical appraisal, } \\
\text { or based on physiology, } \\
\text { bench research or "first } \\
\text { principles" }\end{array}$ & $\begin{array}{l}\text { Expert opinion } \\
\text { without explicit critical } \\
\text { appraisal, or based } \\
\text { on physiology, bench } \\
\text { research or "first } \\
\text { principles" }\end{array}$ & $\begin{array}{l}\text { Expert opinion without explicit critical } \\
\text { appraisal, or based on economic } \\
\text { theory or "first principles" }\end{array}$ \\
\hline \multicolumn{6}{|c|}{$\begin{array}{l}\text { Note: Produced by Bob Phillips, Chris Ball, Dave Sackett, Doug Badenoch, Sharon Straus, Brian Haynes, Martin Dawes since November } 1998 . \\
\text { Updated by Jeremy Howick March } 2009 .\end{array}$} \\
\hline
\end{tabular}

Table 2: Grades of Recommendation.

\begin{tabular}{|l|l|}
\hline A & consistent level 1 studies \\
\hline B & $\begin{array}{l}\text { consistent level } 2 \text { or } 3 \text { studies or extrapolations from level } 1 \\
\text { studies }\end{array}$ \\
\hline C & level 4 studies or extrapolations from level 2 or 3 studies \\
\hline D & $\begin{array}{l}\text { level } 5 \text { evidence or troublingly inconsistent or inconclusive } \\
\text { studies of any level }\end{array}$ \\
\hline
\end{tabular}

Note: Produced by Bob Phillips, Chris Ball, Dave Sackett, Doug Badenoch, Sharon Straus, Brian Haynes, Martin Dawes since November 1998. Updated by Jeremy Howick March 2009.
Table 3: Meaning of grades of recommendation.

\begin{tabular}{|l|l|}
\hline A & Extremely recommended. \\
\hline B & Favorable recommendation, \\
\hline C & Positive but not conclusive recommendation. \\
\hline D & Neither it is recommended or disapproves. \\
\hline
\end{tabular}

Note: Produced by Bob Phillips, Chris Ball, Dave Sackett, Doug Badenoch, Sharon Straus, Brian Haynes, Martin Dawes since November 1998. Updated by Jeremy Howick March 2009. 
Table 4: Assessment of risk of bias trials.

\begin{tabular}{|l|l|}
\hline \multicolumn{1}{|c|}{ Description } & $0:$ not mentioned, it is not clear, $1:$ It is reported, but not confirmed, $2:$ Reported and confirmed \\
\hline Sample size calculation & $0:$ Inadequate, 1: Possibly suitable, 2: Clearly right \\
\hline Allocation concealment & $0:$ Inadequate, 1: Possibly suitable, 2: Clearly right \\
\hline Randomization & $0:$ Do not mention it, it is not clear, 1: Yes / no looses \\
\hline Losses & $0:$ No, 1: Unclear, 2: Yes \\
\hline Blinding of assessors & $0:$ No, 1: Unclear, 2: Yes \\
\hline Appropriate statistical analysis & \\
\hline
\end{tabular}

*Own analysis

- BOP decrease (\%)

- Gingival recession ( $\mathrm{mm}$ )

- LOE EMBC

- Grade of recommendation EMBC

- Ethical aspects

For the development of this review based on the established objectives, he posed the following research question: What is the efficacy and indications of surgery in the treatment of periimplantitis?

\section{Development}

Today the rise of osseointegrated implants and their use in modern dentistry has been described as an effective and permanent solution both to restore missing teeth and other uses in the dental work [1].

While use in the restoration of missing teeth has become commoditized, the technique has been perfected and has a success rate above $90 \%$, however, the failure in this type of treatments exist, with various forms of clinical expression [1].

Among the diseases that could cause the failure of the implants are periodontal diseases such as perimucositis (reversible) and peri-implantitis (irreversible). It is in the latter where there is no general consensus as to what treatment needed for each case, and how effective they will have both short and long term and indications of surgical treatment [1].

The difficulty encountered in defining the treatment of peri-implantitis due to the variety of techniques and available therapies described today in the scientific literature [1].

The treatment of peri-implantitis is scheduled to go from the least invasive and expensive for the patient, to the less conservative. Among the invasive treatments is surgical periodontal therapy [1].

Because surgical periodontal therapy has a high cost and invasiveness compared with non-surgical therapies, the need to describe what their indications and effectiveness of these procedures [1].

\section{Peri-implantitis}

Definition: Peri-implantitis is defined as the inflammatory process that affects tissues surrounding an implant osseointegrated (IOI) function, resulting in loss of bone support, however, and the peri-mucositis and inflammatory the process surrounding tissue defines a implant, no bone loss. It is known that bone loss associated with peri-implantitis or circumferential usually funnel-shaped, unlike the cause periodontal bone loss which is located on one side or tooth surface [1]. Furthermore, the morphology of bone defects seems to be influenced by the macroscopic shape of the implants and has different characteristics depending on the design of the implant and the surface structure thereof. Thus, around the threaded implants defects appear flatter and horizontal, however, around the cylindrical implants bone defects has more angular shape, ie they are vertical [1].

Prevalence: The prevalence of peri-implantitis, according to Esposito, et al. [7] and Mombelli, et al. [8] ranges from 2-10\%, either in the evaluation in relation to the number of patients or the number of implants affected. Also they mention that it can cause failure and the loss of the implant, and that this bone loss, would be associated with the accumulation of plaque, smoking and local etiological factors.

Ethiology: The loss of bone around the implant generally attributed to various processes including: inadequate surgical technique, failure to achieve osseointegration, premature loading, biomechanical overload, peri-implant infection and altered host response. But of them all, the peri-implant infection and biomechanical overload are the etiological factors involved in the progressive loss of bone implants already osseointegrated and function. Their appearance requires early diagnosis and treatment to avoid implant failure [9].

Regarding the peri-implant infection, this would be associated with gram negative bacteria, primarily $P$. gingivalis and $P$. intermedia. However, other bacteria, including fungi, may be associated with the peri-implanitis [10].

Clinical and radiographic features: It has traditionally been accepted that these factors (such as inadequate surgical technique, failure in osseointegration, etc.) bone loss, both the peri-implant infection and overload osseointegrated implant, producing peri-implantitis. However, scientific evidence of either in the genesis of peri-implantitis is quite controversial. There is now abundant information about the role of bacteria in the etiology of peri-implantitis [11]. 
Meanwhile, the clinical and radiographic features of periimplantitis are: DEPTH at greater than $4 \mathrm{~mm}$ and obvious radiographic bone loss cratheterization [12].

Regarding occlusion, in humans, there is insufficient evidence to support the occlusal overload manifests with progressive marginal bone loss that leads to loss of osseointegration and implant failure [11].

Meanwhile, the study of Branemark [13] on the use of implants in dogs gives us an approach to the response of periimplant tissues against the accumulation of plaque and its ability to manage inflammatory lesions, both periodontitis and peri-implantitis. In short, this classic study of implantology, was conducted in dogs to which unilateral mandibular premolars, where implants were placed, which were connected was loss three months later.

During this time remained adequate plaque control until a specific day, and then the formation of periodontitis and periimplantitis for 6 months was induced after that clinical tests, radiographic studies, bacterial samples and biopsy sites were conducted. These results were described and analyzed, finding similarities and differences between the two conditions. There was observed deep pockets, the amount of plaque and bacterial species (gram negative and anaerobic) were similar, which were subsequently corroborated in human studies. However, in this same study also it indicated that there are numerous differences in the micro biota present in the different pathologies mentioned [13].

Furthermore, it was observed that there was a remarkable difference in the size and location of inflammatory lesions: inflammation in periodontitis was separated from the bone tissue, while in the peri-implantitis, it extended into bone spaces core. Therefore it was concluded that the pattern of spread was different and that this is due to the peri-implant tissues would be poorly organized, so that would unable to solve alone progression of inflammatory diseases associated plate. It is for these findings described, that the existence of a difference between periodontitis lesions and peri-implantitis is completed [13].

Risk factors: The established risk factors for periimplantitisson. Prior history of periodontitis, smoking and poor control of plaque [12].

They have also been classified as conditions conducive to, or are the direct cause of the marginal bone loss of peri-implant tissue: overload, poor bone quality, trauma to the periosteum a deep implant placement, implant placed too close adjacent teeth or implants, improper surgical technique or delayed o instant type load, overheating during bone drilling procedures, trauma of the bone bed by over tightening of the implant, the surface structure of the implant, biologic width invasion, lack of facial bone, the implant misalignment, one-piece implants versus two-piece implants, remaining excess cement, inappropriate restorations, restorations and plaque accumulation at the interface between the soft tissue and the implant [9].

In a systematic review of Renvert, et al. [14], are also added other possible risk factors for peri-implantitis, among them we find the presence of teeth, which act as a reservoir for pathogenic bacteria implants. The smoking habit is also mentioned as a risk indicator of peri-implantitis, and heavy smokers exist a genetic polymorphism in the development of pathology. So also he says that diabetes and cardiovascular diseases may be associated with this disease.

Diagnosis: Although there is no defined as diagnosis regarding periimplantitis consensus, it is known that the combination of two aspects is necessary; inflammation of the peri-implant tissues and progressive loss of bone tissue [15]. According Ferreira et al. [16] must be submitted three criteria: depth to greater than or equal to $5 \mathrm{~mm}$ probing, bleeding on probing and bone loss vertically.

Radiographic evidence is preferably performed with a periapical radiograph. Also, it has recently described the use of cone-beam CT, in order to assess bone loss in the three directions of space [12].

Treatment: In general, in the treatment of peri-implantitis, we should make it clear that the first pre-implant placement action would address the risk factors and not just treat them when they have already appeared biological complications. It is also important to control systemic health of the patient, smoking and achieve good hygiene technique; the index represents an optimal hygiene for the maintenance of the implant and make a schedule periodontal maintenance therapy regularly with patient engagement. And in cases where the disease is present, it is important to treat periodontal disease, periodontitis, pretreatment of peri-implantitis.

Once the diagnosis analysis previously described on the inflammatory response of the peri-implant tissues, and the most relevant data are de characteristics of the surface and morphology of implants that can influence the appearance of peri-implantitis and flora made peri -implantpatógenic, we are ready to face this problem therapeutics. Obviously, the primary goal of treatment of peri-implantitis is to stop the progression of bone loss, controlling bacterial infection.

Treatment of peri-implant infection has several aspects, being necessary to consider all for healing. First the necessary cleaning of theeliminaciónde causing bacteria present in the pocket along with the decontamination of the implant surface, the reduction or elimination of the areas that cannot be kept free plate through maneuvers oral hygiene, the contamination or prevent the onset of peri-implant mucositis and, ultimately, regeneration of lost bone.

In the "Proceedings of the 3rd European Workshop on Periodontology" [17] a logical tree therapeutic action, which are clinical parameters used bag size peri-implant, evidence 
of bone loss, the presence of bacterial plaque and described bleeding on probing, giving different treatment options based on the presence or absence of some of these clinical parameters.

Thus, the presence of plaque in peri-implant pockets with dimensions less than $4 \mathrm{~mm}$ and bleed gentle probing, apply Level A treatment that involves mechanical cleaning and improved oral hygiene of the patient. The removal of hard deposits around the abutments and prosthetics are made with scalers and instruments with active tip soft, either plastic or soft metals that will not scratch the structure polished titanium components, and then make a polished thorough with rubber cups and not abrasive paste, a strong emphasis on patient education standards and domestic oral hygiene care [17].

In situations where we are in the presence of plaque and bleeding on probing, but with pockets peri-implant $4-5 \mathrm{~mm}$, the realization of a radiological control of the height of the bone margin to assess comparatively with $\mathrm{X}$-rays will be needed above, the presence or absence of bone loss. If there is loss to the therapeutic measures described in a level would add the use of antiseptic therapy, recommending the use of clorhexidine digluconate rinses $0.1-0.2 \%$, irrigation solutions sack declorhexidine $0.2 \%$ or local application of chlorhexidine gel (level B) [17].

If the depth is greater probing of $5 \mathrm{~mm}$ and bleeding on probing would be necessary to add the $\mathrm{B}$ level of treatment the administration of antibiotic therapy, antibiotic knowing the difficulty of reaching inside the bag, either with insertion procedures Inside the sack of local delivery devices or systemically, prior specific microbiological pathogen detection study and subsequent culture and sensitivity (level C) [17].

Finally, in the presence of the same previous clinical situation but with radiographic evidence of bone loss, it will be recommended level $\mathrm{D}$ treatment, consisting of extending the therapeutic range with surgery to modify or change the morphology of the peri-implant tissue. The aim of surgery is to modify the morphology of the soft tissues and the bone defect caused by peri-implant, while achieving easy maintenance area hygiene for the patient disease [17].

In short, it is the shape and size of the defect as determined by the type of surgery performed, resective or regenerative. Resective therapy is indicated to reduce periodontal pockets, negative bone architecture, correct and modify the surface roughness of the implants concerned and horn to achieve an increase in area of keratinized attached gingiva, if necessary. Regenerative surgery will also be indicated to reduce the size of the periodontal pockets and bone defects, but not the direction of removing tissue but in order to regenerate the missing bone [11].

The evidence currently available does not allow any concrete specific recommendation on the surgical treatment of periimplantitis. However, we can say that there are therapeutic elements that appear to be beneficial, as are the surgical access through a full thickness flap to allow for cleaning surfaces contaminated implants, combined with systemic antibiotics and chlorhexidine rinses during the healing phase. It has also been found to produce bone grafts to stabilize the implant in the bone defect [18].

Types of therapeutic procedures: For the treatment of peri-implantitis, various methods have been suggested, alone or in combination, including: mechanical debridement, pharmacological therapy (subgingival chlorhexidine irrigation and antibiotics, local or systemic) and surgical therapies. Surgical procedures include open flap debridement, aimed at removing bacteria (using soft lasers), smoothing the surface of the implant (to reduce surface roughness) and removing the implant threads allowing the permanence of the plaque, and decontamination or detoxification of the implant surface using several chemical or laser agents [7].

After the main goal of surgery (i.e, the complete bacterial removal of the implant surface) has been achieved, it will be necessary to correct anatomical factors to improve control of the board and to remove the favorable environment for anaerobic bacteria (peri-implant pocket removal). This can be achieved either with resective procedures or, alternatively, with bone regeneration procedures, such as guided bone regeneration, and autologous or allogeneic bone grafts [7].

The failures of the implants are classified as early or late failures. In both cases, the infection may be present. IOI biological involve complications of abscesses or fistulas, and alveolar bone loss due to chronic peri-implant character (periimplantitis) infection [7].

The justification for the treatment of mucositis and periimplantitis is based on the idea that biofilm formation plays an essential role in the etiology of these infections. Therefore, the treatment of peri-implant infection is cause and effect, and aims to reduce the bacterial load around the implant completely [7].

Mucositis is a reversible inflammatory disorder, where in tissue debridement and decontamination of the surface of the implants have proven effective in restoring the health of the peri-implant tissue. Mouthwashes also improve mechanical debridement procedures. However, non-surgical treatment of peri-implantitis has shown an unpredictable and poor effect on clinical parameters such as bleeding on probing in depth to reduce bone loss deep level. Other approaches to control biofilm implants, such as laser therapy and photodynamic therapy have shown small to moderate effects on the peri-implantitis [7].

Antibiotic therapy, both local and systemic level, in association with mechanical debridement has demonstrated clinical benefits in the treatment of periodontitis. The use of antibiotics has also been applied in the treatment of periimplantitis [19].

No clinical study shows the effect of antibiotics as monotherapy in the treatment of peri-implantitis. In all clinical 
trials, administration of antibiotics is always associated with either non-surgical or surgical procedures. There is also no randomized double-blind, placebo-controlled trials, which are available to assess the clinical effects of systemic antibiotic therapy as an adjunct to non-surgical or surgical treatment of peri-implantitis. This leaves the question open as to which antibiotic use, whether delivered systemically or locally and its contribution to the clinical outcome of the treatment of periimplantitis [19].

In a clinical trial Mombelli [8] clinical and microbiological effects of non-surgical treatment of peri-implantitis in conjunction with systemic antibiotic treatment. En him, the treatment of peri-implantitis were documented included: mechanicaldebridement ofall surfaces accessible, irrigation periimplant with $0.5 \%$ chlorhexidine, and systemic administration of ornidazole (1,000 mg daily for 10 days) and using mouthwash during the 10 days of systemic antibiotic treatment. The clinical result was a significant reduction in probing depth, bleeding on probing and a marked suppression of the anaerobic microflora during the 12 months follow up. In certain bone filling lesions it was also observed. The study showed that the combination of local debridement and disinfection in combination with a systemic antibiotic therapy may improve clinical parameters of peri-implantitis lesions, and that these changes can be kept for at least one year. Despite these results, there was no control group, and doses of antibiotics were not mentioned, so it is not possible to conclude that systemic antimicrobials are effective in controlling peri-implantitis [19].

At present there is only one study [20] available describing the effects of surgery and systemic antimicrobial therapy in patients with peri-implantitis. The study is a series of cases, subjects showed bone loss, bleeding on probing and/or drainage of periimplant pockets The intervention included surgical exposure of implants with peri-implantitis, local cleaning with hydrogen peroxide $10 \%$, removal of granulation tissue, sterilization of the pillars and replaced. After surgery, rinsed with chlorhexidine $0,2 \%$ for 14 days. 9 patients in six different antibiotics after examining the microbiological composition of biofilm were used. During the 5 years of maintenance, retreatment with the same combination of antibiotics and surgery was performed when a higher marginal bone loss was observed. After 5 years, 7 of 26 implants were lost (27\%), 4 of 26 showed a continuous loss of bone tissue, 9 of 26 implants showed bone level maintenance, and 6 of 26 sites show and upgrade bone level surrounding the implants. The authors concluded that the treatment was successful in $58 \%$ of the implants. Since there was no control group, it is not possible to determine the additional effects of various regimens of systemic antibiotics [19].

The advantages of locally administered antibiotics compared with systemic antibiotics are:

- Antibiotic concentration is increased.

- The risk of side and adverse effects is reduced.
- No interaction with other drugs.

- The risk of antibiotic-resistant bacteria is reduced.

- It is independent of patient compliance due to professional drug delivery.

In all studies that describe the clinical effects of locally delivered antibiotics, antimicrobials in combination with nonsurgical treatment is used. Treatment consisted of mechanical debridement and cleaning of all structures of implants, and chemical disinfection as the chlorhexidine or hydrogen peroxide. Irrigation with chlorhexidine has also been applied as a supplement in some estudios. The antibiotics that have been tested in the control of peri-implantitis, he tetracycline group, showing successful results [19].

Regarding the current approach in the treatment of periimplantitis, the surgical procedures mode which provides better results. There are many techniques and combinations including, for this study, we will select four main techniques, in order to compare them.

An effect deep it may be susceptible of regeneration, while a surface defect may respond more favorably to single-access surgery. With the increasing prevalence of peri-implantitis, there is an urgent need to identify an effective treatment procedure [21].

One goal of surgical therapy is effective access for surface decontamination. Surfaces contaminated by microorganisms are not conducive to bone-forming cells; therefore, the decontamination of the surface is essential for the reosseointegration [21].

Mechanical means detox surface have been used regularly. The implantoplastic procedure is a radical form of mechanical surface treatment, and has been shown to be effective in halting the loss of marginal bone [1].

The chemical therapy, root included and application of conditioners, disinfectants and antibiotics on the implant surface, results have shown equivalent mechanical treatment.

The carbon dioxide laser $\left(\mathrm{CO}_{2}\right)$, erbium: yttrium-aluminumgarnet (Er: YAG) have shown some promising results, but still the most effective detoxification protocol implant surface not yet been found.

Clinical and radiographic parameters, eg the degree of resolution of inflammation, decreased probing depth (PS), and bone filing are indicators to evaluate the efficacy of these surgical procedures [21].

Four groups of surgical treatment were evaluated in this study:

Surgical Access (CA): A surgical procedure is achieved by lifting a flap that a tooth extends beyond the defect, vertical incisions provide surgical access and visibility for the preparation of the defect. This method provides an excellent 
coating with soft tissue. For this, the elimination of all infected granulation tissue to access the alveolar process and the remaining bone defect, and this followed by preparation of the implant surface is needed. Both methods are tedious in the apical part of the defect.

Resective Surgery (CR): The purpose of this technique is to create or establish a compatible bone base with the gingival tissue overlying, and in some cases they are associated with the use of bone grafts to restore lost anatomy bone defect.

Bone Graft (ITO): sensitive technique whose viability is given by the level of success he aims to get the clinician. Defects larger will have a success rate lower than the smaller ones. Although bone graft technique is not entirely successful, it is possible in other interventions such as resective surgeries, getting better achieve residual defects.

Guided Bone Regeneration (GBR): is for stimulating the formation of new bone tissue, based on the use of a physical barrier, such as the case of membranes and other materials, to prevent the invasion of other tissues and achieve compartmentalization necessary for creating either tissue. This technique can also be associated with the techniques described above.

The choice of one of these techniques does not prevent the use of other, as evidenced in numerous articles in scientific evidence. Furthermore, the use of materials and inputs such as therapeutic aids different forms is changed. So, you may find the use of membranes, using laser, irrigating, drugs, etc.

\section{Results}

As a result of electronic literature search in relation to types, efficacy and indications of surgical treatment of periimplantitis, a total of 6,167 items were found, of which there were 343 items, after applying filters finder, potentially relevant. Of these, 256 were dismissed for not meeting the inclusion and exclusion criteria; and 65 did not answer the research question. Finally, was reduced to a total of 22 articles were included in this review. The selected studies correspond to 12 case series [2334], 5 randomized clinical trials [35-39] and 5 non-randomized [40-44].

Regarding the ethical aspects, most studies were conducted under the guidance and approval of ethics committees and/ or under the signature of informed consent, explained orally and in writing. Only 6 studies did not explain these aspects $[23,26,30,35,40,41]$.

Of a total of 22 studies, the total sample of 435 patients with age ranges and sex unknown. Smoking In 15 studies, one excluded the patients [29] and 6 did not report whether they were smokers $[23,26,27,34,40,41]$ were included.

The total number of implants evaluated in 22 studies was a total of 611 , with follow-up varied between studies, which were ranges from 3 to 91 months after surgery performed. Most implants used were rough surface, or a mixture of smooth and rough. In 6 studies it was unable to find their characteristics $[17,22,24,27,28,35]$.

With respect to the depths of bone defects, these defects ranged from greater than $1.8 \mathrm{~mm}$ to $9.45 \mathrm{~mm}$. Some studies did not provide this information $[30,31,35,41]$.

Antibiotic use was reported in 14 studies [24,26-28,30-32,34$36,38,40,42-44]$, they were not used in 5 of them $[23,25,29,39,41]$ and 2 of them do not report $[33,37]$.

As for the surgical techniques used, 10 studies conducted guided bone regeneration (GBR) [23-28,32,33,37,38], 3 bone graft (ITO) [30,31,34], 2 surgery Access (CA) [29,44], 2 other surgical resection (CR) $[35,39]$. There were also some that combined two of these techniques, ITO and ROG $[40,42,43]$, CA and ROG [41] and CA and ITO [36]. In most implementing the methodologies employed, the use of adjuvant elements (such as types of grafts, irrigating, etc.) was described in detail. Only two studies [29,35,39] do not use adjuvant. Regarding the use of membranes 7 studies used resorbable membranes [24,27,28,37,38,40,43], 6 studies occupied nonresorbable membranes $[23,25,26,32,33,42]$ and 9 non- they used membranes [29-31,34-36,39,41,44]. As for the evaluated parameters, generally these studies evaluated 5 of them:

Reduced probing depth: This parameter was evaluated in most studies, either in millimeters $(\mathrm{mm})$ or percentage $(\%)$. Only 3 studies was not assessed [27,30,42].

- Bone Gain: Parameter evaluated in studies [26-28,30$32,34,36,38,40,42,43]$, and was measured in millimeters (mm).

- Gain clinical attachment level: This parameter was evaluated in 10 studies [18,19,22,23,26,27,29,31,34,35], either in millimeters $(\mathrm{mm})$ or percentage (\%).

- Bleeding on probing (BOP) in 11 studies evaluated Index $[24,25,28,29,31,33,34,37-39,44]$ and bleeding measured in percent (\%).

- Gingival recession: Parameters evaluated in 9 studies $[24,25,28,33-35,37,41,44]$ and measured in millimeters $(\mathrm{mm})$. Information on survey data is summarized in table 5. As for the methodology of the studies and the risk of bias, the information is summarized in tables $6,7,8$ and 9.

\section{Discussion}

In recent years we have seen that there have been a lot of studies in scientific literature regarding the peri-implantitis and surgical treatment, which indicates the importance that this disease has had in the last decade.

Despite the increase of scientific publications on the subject, they have evaluated and used many types of surgical treatments of peri-implantitis, so all these studies have yielded different results. This diversity of the studies suggests a revision by the approval of criteria used by the authors to correct further analysis. 
Table 5: Data studies.

\begin{tabular}{|c|c|c|c|c|c|c|c|c|c|c|c|}
\hline \multicolumn{2}{|l|}{ Author } & Year & \multicolumn{2}{|c|}{$\begin{array}{l}\text { Number of } \\
\text { patients (n) }\end{array}$} & Sex (F/M) & \multicolumn{2}{|c|}{$\begin{array}{l}\text { Average age } \\
\text { (years) }\end{array}$} & \multicolumn{2}{|c|}{$\begin{array}{l}\text { Smokers } \\
\text { (Yes/No) }\end{array}$} & $\begin{array}{l}\text { Follow-up } \\
\text { (months) }\end{array}$ & Implants (n) \\
\hline \multirow{2}{*}{\multicolumn{2}{|c|}{ Romanos et al. [23] }} & \multirow{2}{*}{2008} & \multirow{2}{*}{15} & \multirow{2}{*}{\multicolumn{2}{|c|}{ NR }} & \multicolumn{2}{|c|}{56.5} & \multirow{2}{*}{\multicolumn{2}{|c|}{ NR }} & \multirow{2}{*}{27} & 10 \\
\hline & & & & & & & & & & & 9 \\
\hline \multicolumn{2}{|l|}{ Schwarz et al. [24] } & 2014 & \multicolumn{2}{|l|}{10} & $5 \mathrm{M} / 5 \mathrm{~F}$ & \multicolumn{2}{|c|}{55.8} & \multicolumn{2}{|c|}{ Yes } & 6 & 13 \\
\hline \multirow{3}{*}{\multicolumn{2}{|c|}{ Schwarz et al. [25] }} & & & & & & & & & & 9 \\
\hline & & 2010 & 27 & & & & & Yes & & 12 & 9 \\
\hline & & & & & & & & & & & 9 \\
\hline Froum et al [26] & & 2012 & 38 & & & & & NR & & 36 × 91 & 19 \\
\hline & & & & & & & & 1010 & & ז & 32 \\
\hline Haas et al. [27] & & 2000 & 17 & $4 \mathrm{M}$ & $13 \mathrm{~F}$ & & & NR & & 9.5 & 24 \\
\hline Matarasso et al. [28] & & 2014 & 11 & $6 \mathrm{M}$ & $5 \mathrm{~F}$ & & & Yes & & 12 & 11 \\
\hline Máximo et al. [29] & & 2009 & 13 & $7 \mathrm{M}$ & $6 \mathrm{~F}$ & & & No & & 3 & 20 \\
\hline Mijiritsky et al. [30] & & 2013 & 16 & $8 \mathrm{M}$ & $8 \mathrm{~F}$ & & & Yes & & 6 y 15 & 18 \\
\hline 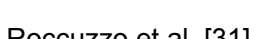 & & 2011 & 26 & $5 \mathrm{M}$ & $9 \mathrm{~F}$ & & & Yoc & & 12 & 14 \\
\hline 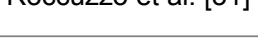 & & 201 & 20 & $5 \mathrm{M}$ & $7 \mathrm{~F}$ & & & 100 & & 12 & 12 \\
\hline Roos-Jansåker et al. & [32] & 2007 & 12 & $3 \mathrm{M}$ & $9 \mathrm{~F}$ & & & Yes & & 12 & 16 \\
\hline Schwarz et al. [33] & & 2009 & 9 & & & & & Yes & & 48 & 9 \\
\hline Wiltfang et al. [34] & & 2012 & 22 & $10 \mathrm{M}$ & $12 \mathrm{~F}$ & & & NR & & 12 & 36 \\
\hline Romeo et al [35] & & 2005 & 17 & & & & & Yes & & 24 y 36 & 19 \\
\hline 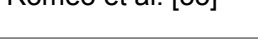 & & & 1 & & & & & & & 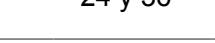 & 14 \\
\hline Wohlfahrt et al. [36] & & 2012 & 16 & $7 \mathrm{M}$ & $9 \mathrm{~F}$ & & & Yes & & 12 & 16 \\
\hline & & & & & & & & & & & 14 \\
\hline Schwarz et al. [37] & & 2012 & 24 & & & & & Yes & & 24 & 10 \\
\hline & & & & & & & & & & & 22 \\
\hline Agnazaden et al. [38 & & 2012 & 45 & & & & & Yes & & 12 & 23 \\
\hline De Waal et al. [39] & & 2013 & 30 & & & & & Yes & & 12 & 31 \\
\hline & & & & & & & & 100 & & & 48 \\
\hline Ronne ot al [41] & & 2007 & 16 & & & & & NIR & & 63 & 11 \\
\hline Deppe et al. [4 I] & & 2001 & 10 & & & & & int & & 00 & 13 \\
\hline Khoury et al. [40] & & 2001 & 7 & $1 \mathrm{M}$ & $6 \mathrm{~F}$ & & & NR & & 6 & 12 \\
\hline Roos-Jansåker et al & [43] & 2014 & 25 & & & & & Yes & & 60 & 23 \\
\hline & & & & & & & & res & & 00 & 22 \\
\hline Roos-Jansåker et al. & [42] & 2011 & 15 & $7 \mathrm{M}$ & $8 \mathrm{~F}$ & & & Yes & & 36 & 27 \\
\hline Heitz-Mayfield et al. & [44] & 2012 & 24 & & & & & Yes & & 12 & 36 \\
\hline TOTAL & & & 435 & & & & & & & & 611 \\
\hline Author & & plant s & ace & $\begin{array}{c}\text { Probing } \\
\text { depth }(\mathbf{m m})\end{array}$ & $\begin{array}{r}\text { Antib } \\
\text { (Yes }\end{array}$ & $\begin{array}{l}\text { iotics } \\
\text { (No) }\end{array}$ & $\begin{array}{r}\text { Su } \\
\text { inter }\end{array}$ & $\begin{array}{l}\text { cal } \\
\text { ntion }\end{array}$ & & Aids & $\begin{array}{l}\text { Using membrane } \\
\text { (Yes/No) }\end{array}$ \\
\hline Romanos et al [23] & & $N R$ & & 9.45 & & $\ln$ & & & & Autograft & Not resorbable \\
\hline Tumarius el al. [20] & & IVT & & 7.42 & & & & & & Xenograft & membrane \\
\hline Schwarz et al. [24] & Smoo & Rough/I & dentifiable & $>3$ & & $\mathrm{ii}$ & & & & Xenograft & $\begin{array}{c}\text { Resorbable } \\
\text { membrane }\end{array}$ \\
\hline & & Rous & & & & & & & & & \\
\hline Schwarz et al. [25] & & nooth/F & & $>3.5$ & & lo & & & & Xenograft & $\begin{array}{l}\text { Not resorbable } \\
\text { membrane }\end{array}$ \\
\hline & & Rous & & & & & & & & & \\
\hline Froum et al [26] & & Rous & & $>4$ & & ij & & & & ograft Aloaraft & Not resorbable \\
\hline & & Rous & & & & & & & & & membrane \\
\hline Haas et al. [27] & & Rous & & $>4$ & & si & & & Aut & graft, laser diode & $\begin{array}{c}\text { Resorbable } \\
\text { membrane }\end{array}$ \\
\hline $\begin{array}{l}\text { Matarasso et al. } \\
\text { [28] }\end{array}$ & & NR & & $>2$ & & $\mathrm{si}$ & & & & Xenograft & $\begin{array}{l}\text { Resorbable } \\
\text { membrane }\end{array}$ \\
\hline Máximo et al. [29] & & Lisc & & $>3$ & & lo & & & & No & No \\
\hline
\end{tabular}

Citation: Bellolio M (2018) Surgical Treatment of Peri-Implantitis: Literature Review. Int J Dent Oral Health 4(1): dx.doi.org/10.16966/2378- 


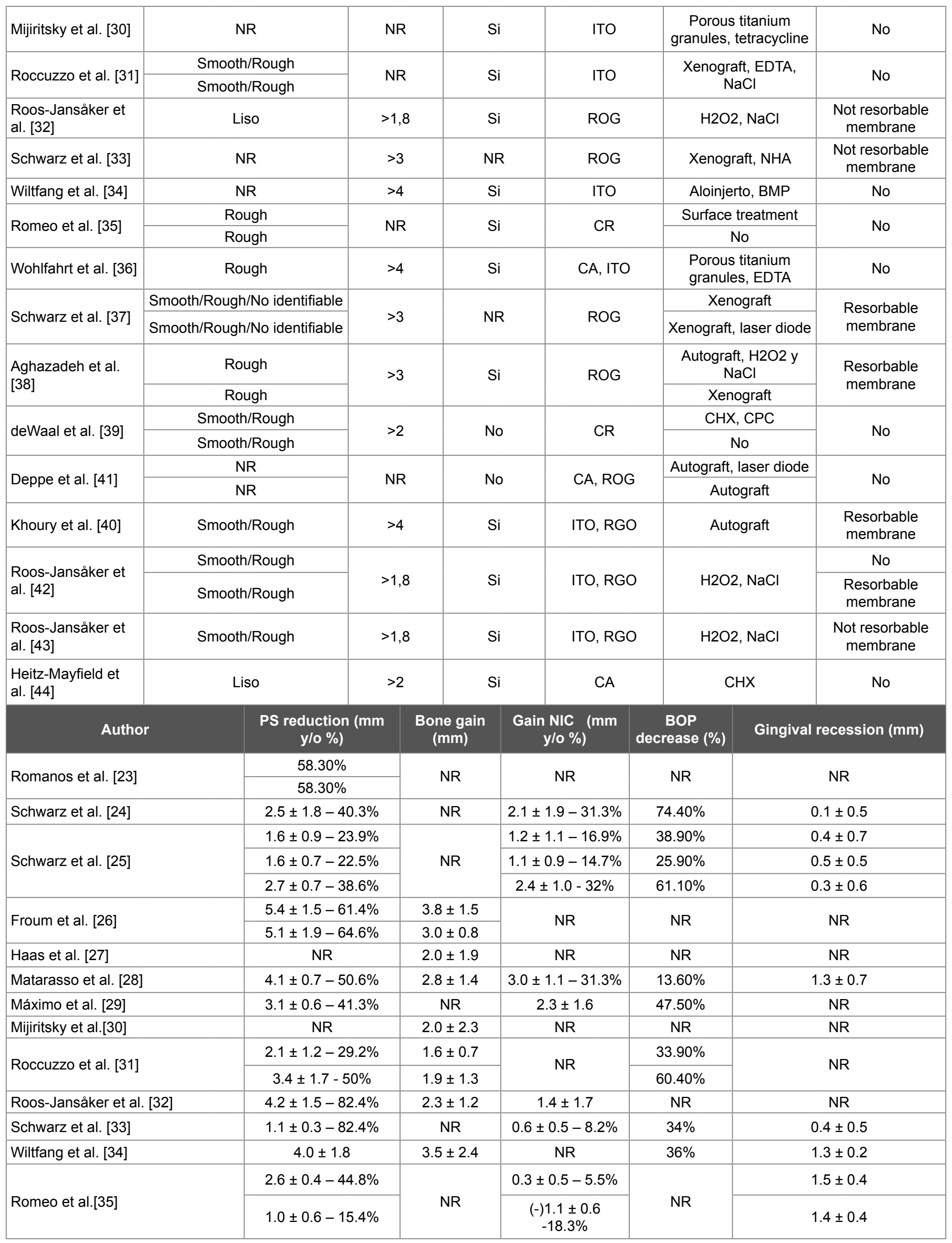




\begin{tabular}{|c|c|c|c|c|c|}
\hline Wohlfahrt et al. [36] & $1.7 \pm 1.7-26.2 \%$ & $2.0 \pm 1.7$ & NR & NR & NR \\
\hline \multirow{2}{*}{ Schwarz et al. [37] } & $1.5 \pm 2.0-28.8 \%$ & \multirow{2}{*}{ NR } & $1.2 \pm 2.2-18.5 \%$ & $54.90 \%$ & $0.3 \pm 0.6$ \\
\hline & $1.1 \pm 2,2-22.4 \%$ & & $1.0 \pm 2.2-15.6 \%$ & $75 \%$ & $0.1 \pm 0.4$ \\
\hline \multirow{2}{*}{ Aghazadeh et al. [38] } & $2.0 \pm 1.2-33.3 \%$ & $0.2 \pm 1.8$ & \multirow{2}{*}{ NR } & $44.80 \%$ & \multirow{2}{*}{ NR } \\
\hline & $3.1 \pm 1.2-50 \%$ & $1.1 \pm 1.9$ & & $50.40 \%$ & \\
\hline \multirow{2}{*}{ deWaal et al. [39] } & $2.3 \pm 0.5-34.8 \%$ & \multirow{2}{*}{ NR } & \multirow{2}{*}{ NR } & $19.90 \%$ & \multirow{2}{*}{ NR } \\
\hline & $1.8 \pm 0.2-32.7 \%$ & & & $22.50 \%$ & \\
\hline \multirow{2}{*}{ Deppe et al. [41] } & $2.3 \pm 0.5-47.9 \%$ & \multirow{2}{*}{ NR } & $2.1 \pm 0.4-35.6 \%$ & \multirow{2}{*}{ NR } & $0.2 \pm 0.6$ \\
\hline & $2.5 \pm 0.5-50 \%$ & & $2.7 \pm 0$ & & $(-) 0.2 \pm 0.5$ \\
\hline Khoury et al. [40] & $5.4 \pm 3.0-65.9 \%$ & $0.2 \pm 1.8$ & & NR & NR \\
\hline \multirow{2}{*}{ Roos-Jansåker et al. [42] } & $3.3 \pm 2.0$ & $1.1 \pm 1.2$ & \multirow{2}{*}{ NR } & \multirow{2}{*}{ NR } & \multirow{2}{*}{ NR } \\
\hline & $3.0 \pm 2.4$ & $1.3 \pm 1.4$ & & & \\
\hline Roos-Jansåker et al. [43] & NR & $1.3 \pm 1.3$ & & NR & NR \\
\hline Heitz-Mayfield et al. [44] & $2.4 \pm 0.3-45.3 \%$ & NR & & $37.50 \%$ & $1.0 \pm 0.9$ \\
\hline Author & LOE EMBC(2) & \multicolumn{2}{|c|}{$\begin{array}{c}\text { Grade of } \\
\text { recommendatión } \\
\text { EMBC }\end{array}$} & \multicolumn{2}{|c|}{ Ethical aspects } \\
\hline Romanos et al. [23] & 4 & \multicolumn{2}{|c|}{ C } & \multicolumn{2}{|c|}{ No reports } \\
\hline Schwarz et al. [24] & 4 & \multicolumn{2}{|c|}{ C } & \multicolumn{2}{|c|}{ Informed consent } \\
\hline Schwarz et al. [25] & 4 & \multicolumn{2}{|c|}{ C } & \multicolumn{2}{|c|}{ Ethics committee, Informed consent } \\
\hline Froum et al. [26] & 4 & C & & & \\
\hline Haas et al. [27] & 4 & C & & & sent \\
\hline Matarasso et al. [28] & 4 & C & & & ent \\
\hline Máximo et al. [29] & 4 & $\mathrm{C}$ & & Ethics comr & med consent \\
\hline Mijiritsky et al. [30] & 4 & C & & & \\
\hline Roccuzzo et al. [31] & 4 & C & & & sent \\
\hline Roos-Jansåker et al. [32] & 4 & C & & & ent \\
\hline Schwarz et al. [33] & 4 & C & & Ethics comr & med consent \\
\hline Wiltfang et al. [34] & 4 & C & & Ethics comr & med consent \\
\hline Romeo et al. [35] & $2 \mathrm{~b}$ & $\mathrm{~B}$ & & & \\
\hline Wohlfahrt et al.[36] & $2 b$ & $B$ & & Ethics comr & med consent \\
\hline Schwarz et al. [37] & $2 b$ & B & & Ethics comr & med consent \\
\hline Aghazadeh et al. [38] & $2 \mathrm{~b}$ & $\mathrm{~B}$ & & & sent \\
\hline deWaal et al. [39] & $2 b$ & $B$ & & Ethics comr & med consent \\
\hline Deppe et al. [41] & 4 & C & & & \\
\hline Khoury et al. [40] & 4 & C & & & \\
\hline Roos-Jansåker et al.[42] & 4 & C & & Ethics comr & med consent \\
\hline Roos-Jansåker et al.[43] & 4 & C & & Ethics comr & med consent \\
\hline Heitz-Mayfield et al.[44] & $2 b$ & B & & Ethics comr & med consent \\
\hline
\end{tabular}

Table 6: Statement STROBE for observational studies [5].

\section{Author}

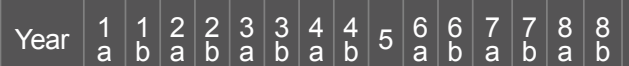

$\left.9 \begin{array}{cc|ccccccccccccc}11 & 11 & 11 & 12 & 12 & 13 & 13 & 14 & 14 & 15 & 16 & 17 & 17 \\ a & b & a & b & a & b & a & b\end{array}\right)$

1819202122232425

\begin{tabular}{|c|c|c|c|c|c|c|c|c|c|c|c|c|c|c|c|c|c|c|c|c|c|c|c|c|c|c|c|c|c|c|c|c|c|c|c|c|c|}
\hline \\
\hline Romeo et al.[35] & 2005 & $x$ & $\sqrt{ }$ & $\sqrt{ }$ & $\sqrt{ }$ & $\sqrt{ }$ & $\sqrt{ }$ & $\sqrt{ }$ & $\sqrt{ } \sqrt{ }$ & $\sqrt{ } \sqrt{1}$ & $\sqrt{ }$ & $\mathrm{x}$ & $\sqrt{ }$ & $\sqrt{ }$ & $x$ & $\sqrt{ }$ & $\sqrt{ }$ & $\mathrm{x}$ & $\sqrt{ }$ & $\sqrt{ }$ & $\sqrt{ }$ & $\sqrt{ }$ & $\sqrt{ }$ & $\sqrt{ }$ & $\sqrt{ }$ & $\sqrt{ }$ & $\sqrt{ }$ & $\sqrt{ }$ & $\sqrt{ }$ & $\sqrt{ }$ & $\sqrt{ }$ & $\sqrt{ }$ & $\sqrt{ }$ & $\sqrt{ }$ & $\sqrt{ }$ & $x$ & $x$ \\
\hline Wohlfahrt et al.[36] & 2012 & $\sqrt{ }$ & $\sqrt{ }$ & $\sqrt{ }$ & $\sqrt{ }$ & $\sqrt{ }$ & $\sqrt{ }$ & $\sqrt{ }$ & $\sqrt{ } \sqrt{ }$ & $\sqrt{ } 1$ & $\sqrt{ } \sqrt{2}$ & $\sqrt{ }$ & $\sqrt{ }$ & $x$ & $x$ & $\sqrt{ }$ & $\sqrt{ }$ & $\sqrt{ }$ & $\sqrt{ }$ & $\sqrt{ }$ & $\sqrt{ }$ & $\sqrt{ }$ & $\sqrt{ }$ & $\sqrt{ }$ & $\sqrt{ }$ & $\sqrt{ }$ & $\sqrt{ }$ & $\sqrt{ }$ & $\sqrt{ }$ & $\sqrt{ }$ & $\sqrt{ }$ & $\sqrt{ }$ & $\sqrt{ }$ & $\sqrt{ }$ & $\sqrt{ }$ & $x$ & $\sqrt{ }$ \\
\hline Schwarz et al.[37] & 2012 & $x$ & $\sqrt{ }$ & $\sqrt{ }$ & $\sqrt{ }$ & $\sqrt{ }$ & $\sqrt{ }$ & $\sqrt{ }$ & $\sqrt{ } \sqrt{2}$ & $\sqrt{ } \sqrt{2}$ & $\sqrt{ } \sqrt{2}$ & $x$ & $\sqrt{ }$ & $\sqrt{ }$ & $x$ & $\sqrt{ }$ & $\sqrt{ }$ & $\sqrt{ }$ & $\sqrt{ }$ & $\sqrt{ }$ & $\sqrt{ }$ & $\sqrt{ }$ & $\sqrt{ }$ & $\sqrt{ }$ & $\sqrt{ }$ & $x$ & $\sqrt{ }$ & $\sqrt{ }$ & $\sqrt{ }$ & $\sqrt{ }$ & $\sqrt{ }$ & $\sqrt{ }$ & $\sqrt{ }$ & $\sqrt{ }$ & $\sqrt{ }$ & $\sqrt{ }$ & $x$ \\
\hline Aghazadeh et al.[38] & 2012 & $\sqrt{ }$ & $\sqrt{ }$ & $\sqrt{ }$ & $\sqrt{ }$ & $\sqrt{ }$ & $\sqrt{ }$ & $\sqrt{ }$ & $\sqrt{ } \sqrt{y}$ & $\sqrt{ }$ & $\sqrt{1}$ & $x$ & $\sqrt{ }$ & $\sqrt{ }$ & $\sqrt{ }$ & $\sqrt{ }$ & $\sqrt{ }$ & $x$ & $\sqrt{ }$ & $\sqrt{ }$ & $\sqrt{ }$ & $\sqrt{ }$ & $\sqrt{ }$ & $\sqrt{ }$ & $\sqrt{ }$ & $\sqrt{ }$ & $\sqrt{ }$ & $\sqrt{ }$ & $\sqrt{ }$ & $\sqrt{ }$ & $\sqrt{ }$ & $\sqrt{ }$ & $\sqrt{ }$ & $\sqrt{ }$ & $\sqrt{ }$ & $x$ & $\sqrt{ }$ \\
\hline de Waal et al.[39] & 2013 & $\sqrt{ }$ & $\sqrt{ }$ & $\sqrt{ }$ & $\sqrt{ }$ & $\sqrt{ }$ & $\sqrt{ }$ & $\sqrt{ }$ & $\sqrt{ } \sqrt{ }$ & $\sqrt{ } \sqrt{ }$ & $\sqrt{ } \sqrt{ }$ & $\sqrt{ }$ & $\sqrt{ }$ & $\sqrt{ }$ & $x$ & $\sqrt{ }$ & $\sqrt{ }$ & $\sqrt{ }$ & $\sqrt{ }$ & $\sqrt{ }$ & $\sqrt{ }$ & $\sqrt{ }$ & $\sqrt{ }$ & $\sqrt{ }$ & $\sqrt{ }$ & $\sqrt{ }$ & $\sqrt{ }$ & $\sqrt{ }$ & $\sqrt{ }$ & $\sqrt{ }$ & $\sqrt{ }$ & $\sqrt{ }$ & $\sqrt{ }$ & $\sqrt{ }$ & $\sqrt{ }$ & $x$ & $x$ \\
\hline
\end{tabular}

Citation: Bellolio M (2018) Surgical Treatment of Peri-Implantitis: Literature Review. Int J Dent Oral Health 4(1): dx.doi.org/10.16966/2378- 
Table 7: Table CONSORT Randomized Clinical Trials [3]

\begin{tabular}{|c|c|c|c|c|c|c|c|c|c|c|c|c|c|c|c|c|c|c|c|c|c|c|c|c|c|c|c|c|c|c|c|c|c|c|c|c|c|c|c|}
\hline Author & Year & 1 & 2 & $\begin{array}{c}3, \\
1\end{array}$ & $\begin{array}{l}3, \\
2\end{array}$ & $\begin{array}{l}3, \\
3\end{array}$ & $\begin{array}{c}4, \\
1\end{array}$ & $\begin{array}{l}4, \\
2\end{array}$ & $\begin{array}{c}4, \\
3\end{array}$ & $\begin{array}{l}4, \\
4\end{array}$ & $\begin{array}{c}4, \\
5\end{array}$ & 5 & 67 & & & 10 & & $\begin{array}{c}12, \\
1\end{array}$ & $\begin{array}{c}12, \\
2\end{array}$ & $\begin{array}{c}12, \\
3\end{array}$ & $\begin{array}{c}12, \\
4\end{array}$ & 5 & 6 & $\begin{array}{c}12, \\
7\end{array}$ & 13 & & & $\begin{array}{c}16, \\
1\end{array}$ & $\begin{array}{c}16, \\
2\end{array}$ & $\begin{array}{c}17, \\
1\end{array}$ & $\begin{array}{c}17, \\
2\end{array}$ & $\begin{array}{c}17, \\
3\end{array}$ & 18 & & $\begin{array}{c}20, \\
1\end{array}$ & $\begin{array}{c}20, \\
2\end{array}$ & $\begin{array}{c}20, \\
3\end{array}$ & & 22 \\
\hline $\begin{array}{l}\text { Deppe et } \\
\text { al. [41] }\end{array}$ & 2007 & $\sqrt{ }$ & $\sqrt{ }$ & $\sqrt{ }$ & $\sqrt{ }$ & $x$ & $\sqrt{ }$ & $x$ & $\sqrt{ }$ & $\sqrt{ }$ & $\mathrm{X}$ & $\sqrt{ } 1$ & $\sqrt{ } x$ & & $X$ & $\sqrt{ }$ & $\sqrt{ }$ & $\sqrt{ }$ & $\sqrt{ }$ & $\sqrt{ }$ & $\sqrt{ }$ & $\sqrt{ }$ & $\sqrt{ }$ & $x$ & $\sqrt{ }$ & $x$ & $x$ & $\sqrt{ }$ & $\sqrt{ }$ & $\sqrt{ }$ & $x$ & $\sqrt{ }$ & $\sqrt{ }$ & $\sqrt{ }$ & $\sqrt{ }$ & $\sqrt{ }$ & $\sqrt{ }$ & $\sqrt{ }$ & $\sqrt{ }$ \\
\hline $\begin{array}{l}\text { Khoury et } \\
\text { al. [40] }\end{array}$ & 2001 & $\sqrt{ }$ & $\sqrt{ }$ & $\sqrt{ }$ & $\sqrt{ }$ & $\sqrt{ }$ & $\sqrt{ }$ & $\sqrt{ }$ & $\sqrt{ }$ & $\sqrt{ }$ & $\mathrm{X}$ & $\sqrt{ }$ & $\sqrt{ } x$ & $x \cdot \sqrt{ }$ & $x$ & $\sqrt{ }$ & $\sqrt{ }$ & $\sqrt{ }$ & $\sqrt{ }$ & $\sqrt{ }$ & $\sqrt{ }$ & $\sqrt{ }$ & $\sqrt{ }$ & $x$ & $\sqrt{ }$ & $\sqrt{ }$ & $\sqrt{ }$ & $\sqrt{ }$ & $\sqrt{ }$ & $\sqrt{ }$ & $x$ & $\sqrt{ }$ & $\sqrt{ }$ & $\sqrt{ }$ & $\sqrt{ }$ & $\sqrt{ }$ & $\sqrt{ }$ & $\sqrt{ }$ & $\sqrt{ }$ \\
\hline \begin{tabular}{|l|} 
Roos- \\
Jansåker \\
et al. [42]
\end{tabular} & 2014 & $\sqrt{ }$ & $\sqrt{ }$ & $\sqrt{ }$ & $\sqrt{ }$ & $\sqrt{ }$ & $\sqrt{ }$ & $\sqrt{ }$ & $\sqrt{ }$ & $\sqrt{ }$ & $\mathrm{X}$ & $\sqrt{ }$ & $\sqrt{ } x$ & $x \sqrt{ }$ & $X$ & $\sqrt{ }$ & $\sqrt{ }$ & $\sqrt{ }$ & $\sqrt{ }$ & $\sqrt{ }$ & $\sqrt{ }$ & $\sqrt{ }$ & $\sqrt{ }$ & $x$ & $\sqrt{ }$ & $\sqrt{ }$ & $\sqrt{ }$ & $\sqrt{ }$ & $\sqrt{ }$ & $\sqrt{ }$ & $x$ & $\sqrt{ }$ & $\sqrt{ }$ & $\sqrt{ }$ & $\sqrt{ }$ & $\sqrt{ }$ & $\sqrt{ }$ & $\sqrt{ }$ & $\sqrt{ }$ \\
\hline $\begin{array}{l}\text { Roos- } \\
\text { Jansåker } \\
\text { et al. [43] }\end{array}$ & 2011 & $\sqrt{ }$ & $\sqrt{ }$ & $\sqrt{ }$ & $\sqrt{ }$ & $\sqrt{ }$ & $\sqrt{ }$ & $\sqrt{ }$ & $\sqrt{ }$ & $\sqrt{ }$ & $\mathrm{X}$ & $\sqrt{ }$ & $\sqrt{ } x$ & $x \sqrt{ }$ & $x$ & $\sqrt{ }$ & $\sqrt{ }$ & $\sqrt{ }$ & $\sqrt{ }$ & $\sqrt{ }$ & $\sqrt{ }$ & $\sqrt{ }$ & $\sqrt{ }$ & X & $\sqrt{ }$ & $\sqrt{ }$ & $\sqrt{ }$ & $\sqrt{ }$ & $\sqrt{ }$ & $\sqrt{ }$ & $x$ & $\sqrt{ }$ & $\sqrt{ }$ & $\sqrt{ }$ & $\sqrt{ }$ & $\sqrt{ }$ & $\sqrt{ }$ & $\sqrt{ }$ & $\sqrt{ }$ \\
\hline $\begin{array}{l}\text { Heitz- } \\
\text { Mayfield } \\
\text { et al. [44] }\end{array}$ & 2012 & $\sqrt{ }$ & $\sqrt{ }$ & $\sqrt{ }$ & $\sqrt{ }$ & $\sqrt{ }$ & $\sqrt{ }$ & $\sqrt{ }$ & $\sqrt{ }$ & $\sqrt{ }$ & X & $\sqrt{ }$ & $\sqrt{ } \sqrt{ }$ & $\sqrt{ } \sqrt{ }$ & $\mathrm{X}$ & $\sqrt{ }$ & $\sqrt{ }$ & $\sqrt{ }$ & $\sqrt{ }$ & $\sqrt{ }$ & $\sqrt{ }$ & $\sqrt{ }$ & $\sqrt{ }$ & $x$ & $\sqrt{ }$ & $x$ & $x$ & $\sqrt{ }$ & $\sqrt{ }$ & $\sqrt{ }$ & $x$ & $\sqrt{ }$ & $\sqrt{ }$ & $\sqrt{ }$ & $\sqrt{ }$ & $\sqrt{ }$ & $\sqrt{ }$ & $\sqrt{ }$ & $\sqrt{ }$ \\
\hline
\end{tabular}

Table 8: Table TREND Non- Randomized Clinical Trials [4].

\section{Author $\quad$ Año 1a 1b 2345 6a 6b 7891011 12a 12b 12c 12d 12e 13a 13b 13c 14a 14b 14c $1516 a 16 c 171819202122$}

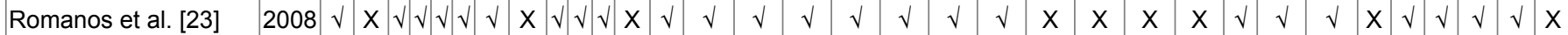

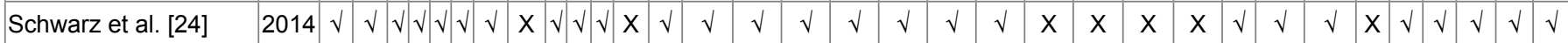

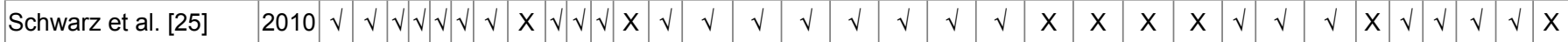

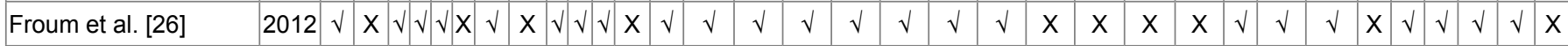



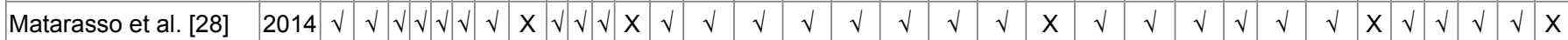

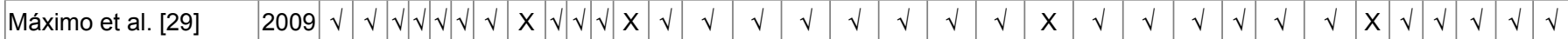



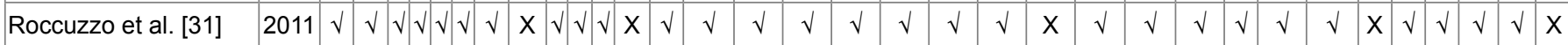

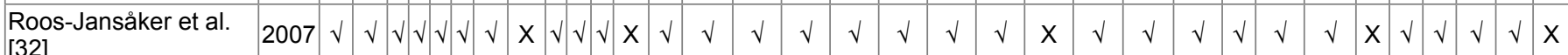

[32]

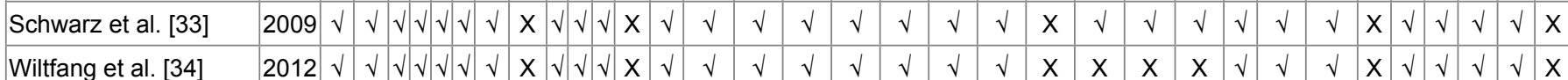

Table 9: Assessment of risk of bias trials.

\begin{tabular}{|c|c|c|c|c|c|c|}
\hline Author & $\begin{array}{l}\text { Sample size } \\
\text { calculation }\end{array}$ & $\begin{array}{l}\text { Allocation } \\
\text { concealment }\end{array}$ & Randomization & $\begin{array}{l}\text { Losses during } \\
\text { the study }\end{array}$ & $\begin{array}{l}\text { Masking } \\
\text { advisers }\end{array}$ & $\begin{array}{c}\text { Appropiate } \\
\text { statistical analysis }\end{array}$ \\
\hline Romanos et al. [23] & 1 & 2 & 2 & 1 & 2 & 2 \\
\hline Schwarz et al. [24] & 1 & 2 & 2 & 1 & 2 & 2 \\
\hline Schwarz et al. [25] & 1 & 2 & 2 & 1 & 2 & 2 \\
\hline Froum et al. [26] & 1 & 2 & 2 & 1 & 2 & 2 \\
\hline Haas et al. [27] & 1 & 2 & 2 & 1 & 2 & 2 \\
\hline Matarasso et al. [28] & 1 & 2 & 2 & 1 & 2 & 2 \\
\hline Máximo et al. [29] & 1 & 2 & 2 & 1 & 2 & 2 \\
\hline Mijiritsky et al. [30] & 1 & 2 & 2 & 1 & 2 & 2 \\
\hline Roccuzzo et al. [31] & 1 & 2 & 2 & 1 & 2 & 2 \\
\hline Roos-Jansåker et al. [32] & 1 & 2 & 2 & 1 & 2 & 2 \\
\hline Schwarz et al. [33] & 1 & 2 & 2 & 1 & 2 & 2 \\
\hline Wiltfang et al. [34] & 1 & 2 & 2 & 1 & 2 & 2 \\
\hline Romeo et al. [35] & 1 & 1 & 2 & 1 & 1 & 2 \\
\hline Wohlfahrt et al. [36] & 2 & 2 & 0 & 1 & 1 & 2 \\
\hline Schwarz et al. [37] & 1 & 2 & 2 & 1 & 1 & 2 \\
\hline Aghazadeh et al. [38] & 1 & 1 & 2 & 1 & 1 & 2 \\
\hline deWaal et al. [39] & 2 & 2 & 2 & 1 & 1 & 2 \\
\hline Deppe et al. [41] & 1 & 1 & 2 & 1 & 0 & 2 \\
\hline Khoury et al. [40] & 1 & 1 & 2 & 1 & 0 & 2 \\
\hline Roos-Jansåker et al.[42] & 1 & 1 & 2 & 1 & 0 & 2 \\
\hline Roos-Jansåker et al. [43] & 1 & 1 & 2 & 1 & 0 & 2 \\
\hline Heitz-Mayfield et al. [44] & 2 & 1 & 2 & 1 & 0 & 2 \\
\hline
\end{tabular}

Citation: Bellolio M (2018) Surgical Treatment of Peri-Implantitis: Literature Review. Int J Dent Oral Health 4(1): dx.doi.org/10.16966/2378- 
Regarding the heterogeneity of the studies, we found many differences in the realization of these, remembering that we both observational studies [23-34], randomized clinical studies [35-39] and non-randomized [40-44], which by their different methodologies used could show differences and similarities in the results, there may be some degree of bias in this review.

However, most of these publications, the number of patients tested were in a range between 7 and 24 with its respective surgical technique, which allows us to increase the comparability these studies. There is no clear determination of the calculation of sample sizes, which generally was conducted by the availability of patients, commitment to the various studies and subsequent monitoring.

Regarding gender, studies point to this aspect do not differentiate on the results for male or female, or results obtained, nor there are studies to evaluate this parameter and its response to different treatments.

For ages, the average age range of patients used in the studies where this aspect is mentioned [23,24,28-32,36,40,42] varies between the ages of 49 and 65 years of average, it would be important to assess the impact of these treatments performed in these age ranges.

It would be important also the systemic knowledge of the state of health of patients in different studies, to assess whether there is any relationship between these conditions and also the effectiveness of treatments performed.

In relation to the habits of the patients, these studies evaluated, in general, smoking, where most of them were included smokers, only one did not include them [29] and others $[23,26,27,34,40,41]$ did not said, which could be another factor of bias in this review. So a larger study to evaluate the tissue response to this factor would be necessary, as well as specify the degree of smoking patients, which is not mentioned in none one of the studies.

Regarding the monitoring carried out after surgical procedures, studies vary from track to 3 to 91 months. In follow-up studies with short periods, you are not allowed bring predict the course and evolution of the executed treatment, it would be necessary to leave more standardized and established tracking specific therapies such dates.

On the number of implants analyzed in studies, they are generally quite heterogeneous, varying between 9 and 48 implants, where a larger sample would be more statistically significant for evaluating these results.

The surface of implants is another feature that is discussed in most studies, only 6 of them do not mention [23,28,30,33,34,41], which may affect clinical outcomes of different therapies. Therefore standardize studies would be useful to make them comparable with respect to this item.

Regarding the defects treated, sack depths were also widely dispersed, defects ranging from 1.8 to $9.45 \mathrm{~mm}$ probing depth, which could also give a bias in our results analyzed. In addition, 4 of these studies $[30,31,35,41]$ do not report the depths of the defects, so the results are not comparable to those that yes they reported.

The use of antibiotics during therapy is another factor that could affect the results, as these can decrease the bacterial reduction product and can promote repair processes in those treated bone defects. Therefore it is important that studies report their use, because they could affect the results. However, in this review only 2 of them were not clarified [33,37].

In the studies analyzed different surgical techniques were used and found to be in most of them, the most common procedure corresponded to the GBR, followed by bone graft, leaving resection surgeries and access surgery. The diversity of these techniques is also a factor present in the results, yet the choice of one technique over another, we could give an indication of the indications of these surgical procedures in different defects But in this review found no differences between the depths of bag found and the choice of a particular technique, therefore, the choice of one procedure or another, would be given by the clinical experience and technical management of either type of surgery.

Regarding the use of adjuvants, there were applications of various materials depending on the effects of each study would analyze and find different types of grafts (auto, xeno and allografts), uses laser proteins bone formation, irrigants (hydrogen peroxide, serum, chlorhexidine and cetyl pyridinium chloride) and other (porous titanium granules and tetracyclines). This diversity also proposes studying these materials separately, to see if they really are necessary, they contribute, and how, in the forecast and what is the efficacy of many adjuvants distintoselementos.

The use of membranes in these procedures appears to be important in the segregation of the spaces involved and subsequent regeneration/repair of lost tissue factor. In this review, only one study [43] compared the use of membranes in surgery on the results of this study. The results showed no statistically significant difference with and without use. Still, it is important to gather more information about its use with clear and convincing evidence, not on display all items that may not be entirely necessary for the above procedures.

Regarding the results, the parameter probing depth, evaluated in millimeters and percentage reduction, depending on the study, all results showed decreased probing depth up to $5.4 \pm 3.0 \mathrm{~mm}$ in the Khoury study [40], and a percentage decline of $82.4 \%$ in studies of Roos-Jansaker and Schwarz [32,33]. This may be related to the defect treated, which is important to clarify, as Khoury discussed major defects to $4 \mathrm{~mm}$, wellJansaker Roos tried defects from $1.8 \mathrm{~mm}$ and Schwarz included defects from $3 \mathrm{~mm}$ which could indicate defects smaller would have a better treatment prognosis. What is also not clear in these studies is the type of defects treated, we know already, the 
scientific evidence of periodontal disease, there are defects that by their anatomy, the number of faces affected and their depths, will have forecasts different, so it is important to describe in detail these conditions.

On the parameter of the back bone gain treatment, as shown in millimeters gain 10 studies analyzed this parameter [23$25,29,33,35,37,39,41,44]$. Studies that analyzed what made using radiographic studies performed prior to therapy and at the time of planned control. As for the results, the study Froum [26] showed the best results, achieving a gain of $3.8 \pm$ $1.5 \mathrm{~mm}$. En counterpart Aghazadeh studies [38] and Khoury [40] showed the worst results $(0.2 \pm 1.8 \mathrm{~mm})$. If these results can be compared because they all used the same surgical technique, since the 3 studies conducted antibiotic therapy and guided bone regeneration, the difference was that forum used non-resorbable membranes, and other studies used resorbable membranes.

The gain of clinical attachment level, assessed in $\mathrm{mm}$ and/ or percentage was analyzed in 10 studies [24,25,28,29,32,33 ,35,37,40,41], the study Matarasso [28] which presented the best results in millimeters, with a gain of $3.0 \pm 1.1 \mathrm{~mm}$. In percentages, the study was to gain greater Deppe [41], who obtained a gain of $42.9 \%$.In both studies they used differente GBR techniques, Making further controversial use of these membranes in relation to its effectiveness in use.

The rate of bleeding or BOP was evaluated in most studies, finding very heterogeneous results, the study of Schwarz [24] showed a decrease in bleeding of $74.4 \%$, whereas the study Matarasso [28] indicated $13.6 \%$. This difference is important, because in the latter study remains a local inflammatory state. However, he used the technique of guided bone regeneration with resorbable membranes, which remains controversial with the results.

As for gingival recession, in all studies that analyzed this issue and improvement in millimeters, only Deppe study [41] showed an increase in this defect of $-0.2 \pm 0.5 \mathrm{~mm}$. The best results were obtained in the study of Romeo [35] with a gain position gum $1.5 \pm 0.4 \mathrm{~mm}$, these studies are important, noting that the aesthetic implant treatment is an important factor in its success clinical for both the patient and the professional. It is important that studies evaluating this parameter to also give patients history, actual forecast data that will have these procedures.

On levels of evidence from studies and level of recommendation, it is noteworthy that most of them have a level 4 according EMBC [2], only $6[35-39,44]$ have a level $2 b$, which have grade of recommendation level $\mathrm{B}$, indicating that they have a favorable recommendation.

Regarding the ethical aspects of these studies, we must consider that any trial should be supported with the approval of an ethics committee or, failing that, the signing of informed consent by patients. In this review, six of these studies
$[23,26,30,35,40,41]$ make no mention of these issues, which removes these studies ethics assessment.

The risk of bias of randomized clinical trials was considered high in five studies [40-44], moderate in 3 [35,36,38], and low in the other 14. Among the factors analyzed by the book of The Cochrane Collaboration, the parameter that involves more methodological quality is the lack of allocation concealment, which makes even the randomization process, may be damaged. The operator can intervene, which tends to favor one group over another, which could lead to a selection bias.

It can be seen that the studies included in this review are varied, in terms of population, intervention, different techniques performed, methods of randomization, the study designs, sample sizes and even individual results, which It does the right difícilel analysis and proper comparison of the data. In addition, only were selected within the inclusion criteria, studies in English and Spanish, which could be a limitation of this study.

We are conducting future randomized, controlled clinical trials with a long follow-up period and with appropriate methodological design, in order to develop future metaanalysis, focusing on the efficacy and indications of the different surgical techniques for the treatment of periimplantitis, as well as the impact of this condition in the quality of life of patients.

\section{Conclusion}

The increased use of osseointegrated implants in dentistry as rehabilitative therapy, and the incidence of peri-implant disease and by the need to solve these patients' oral health problems and maintaining the implants in the oral cavity. They have led to scientific research to develop a set of procedures that seek to improve these conditions. Within these procedures are surgical techniques used to return the peri-implant health. That is why there is a need to determine the efficacy of this treatment and its indications in different defects.

The studies published to date demonstrate the presence of a number of surgical techniques and varieties within them, which have successful results in the restoration of health in terms of peri-implantitis. There is evidence that these surgical procedures leading to better patient-oriented outcomes, including reduced probing depth, improve rates of bleeding, clinical attachment levels and management of gingival recession, also improving the aesthetics of the smile of patients, and these is the reasons of the indications of these procedures.

However, hampered the ability to quantify the effectiveness of different surgical treatments because we need more and better randomized clinical studies whose main objective is to study the different clinical parameters with these types of treatments, as well as adequate standardization of methods diagnosis and identification of the most appropriate technique in each case.

In general, as reviewed above, the Guided Bone Regeneration technique seems to be the technique used in these cases, also getting a lot like the rest of the techniques discussed results. 
In the presence of peri-implantitis, it becomes essential to prevent occurrence of the pathology, as in most periodontal diseases is the most important etiologic factor as the plaque formation, as no surgical procedure one that gets the results of surgery remain stable over time if left unchecked etiological conditions.

It can also indicate that complete coating of the implant should be one of the objectives of the surgical treatment, as only $100 \%$ coverage of the exposed surface of the implant ensures the recovery of aesthetic patient demand.

The results of this review should be analyzed with caution due to the large number of studies are at high or moderate risk of bias. Future research with appropriate methodological designs and longer follow-up, focusing on surgical therapy, are needed to define appropriate treatment lines in literature.

The above could also be useful in the creation of protocols or clinical guidelines for treatment, standardized manner, for the management of patients with peri-implant disease.

Health professional's dental officer must be informed and updated regarding this issue, given the high prevalence of installing implants, which can cause periodontal defects and the high impact that can have on quality of life patients if these implants have to be extracted. They should be aware of the recommendations or existing protocols, preventive measures and proper handling of each case, in order to act in the best way possible and provide the best treatment options for patients.

Therefore, it is essential that patients receiving installation and rehabilitation of osseointegrated implants have a regular monitoring of these and gain the commitment of patients to avoid having to make this type of surgical therapy for resolution peri-implantitis.

Finally, we must work in a multidisciplinary way to determine the risks and benefits of the patient before making a final decision and to indicate a good diagnosis therapy to follow.

\section{References}

1. Lindhe, Niklaus P Lang, Thorkild Karring (2009) Clinical Periodontology and Implantology Odontological. (Ed 5th) Panamericana Medical: 820.

2. (2009) CEBM-Oxford: Centre for Evidence-based Medicine.

3. Consort (2014) Identification as a randomised trial in the title.

4. Vallvé C, Artés M, Cobo E (2005) Non-randomized intervention studies (TREND). Clinical Medicine 125: 38-42.

5. Von Elm E, Altman DG, Egger M, Pocock SJ, Gøtzsche PC, et al. (2008) The Strengthening the Reporting of Observational Studies in Epidemiology [STROBE] statement: guidelines for reporting observational studies. Gac Sanit 22: 144-150.

6. Cochrane Handbook for Systematic Reviews of Interventions.

7. Esposito M, Grusovin MG, Worthington HV (2012) Treatment of peri-implantitis: what interventions are effective? A Cochrane systematic review. Eur J Oral Implantol 5: 21-41.
8. Mombelli A, Lang NP (1992) Antimicrobial treatment of periimplant infections. Clin Oral Implants Res 3: 162-168.

9. Froum S (2011) Dental Implant Complications: Etiology, Prevention, and Treatment. John Wiley \& Sons.

10. Charalampakis G, Leonhardt A, Rabe P, Dahlén G (2012) Clinical and microbiological characteristics of peri-implantitis cases: a retrospective multicentre study. Clin Oral Implants Res 23: 10451054.

11. García-Calderón M, Cabezas Talavero J, Gallego Romero D, Torres Lagares D (2004) Diagnosis and treatment of peri-implantitis. Update in the clinical diagnosis and treatment of periimplantitis. Advances in Periodontics and Oral Implantology 16: 9-18.

12. Academy Report: Peri-Implant Mucositis and Peri-Implantitis: A Current Understanding of Their Diagnoses and Clinical Implications (2013). J Periodontol 84: 436-443.

13. Berglundh T, Lindhe J, Marinell C, Ericsson I, Liljenberg B (1992) Soft tissue reaction to de novo plaque formation on implants and teeth. An experimental study in the dog. Clin Oral Implants Res 3: 1-8.

14. Renvert S, Quirynen M (2015) Risk indicators for peri-implantitis. A narrative review. Clin Oral Implants Res 26: 15-44.

15. Zitzmann NU, Berglundh $\mathrm{T}$ (2008) Definition and prevalence of peri-implant diseases. J Clin Periodontol 35: 286-291.

16. Ferreira SD, Silva GLM, Cortelli JR, Costa JE, Costa FO (2016) Prevalence and risk variables for peri-implant disease in Brazilian subjects. J Clin Periodontol 33: 929-935.

17. Proceedings of the 3rd European Workshop on Periodontology: Implant Dentistry 3rd - AbeBooks: 3876523060.

18. Andrea Mombelli, Rapheal Moene, Fabien Decaillet (2012) Surgical teatment of peri-implantitis. Eur J Oral Implantol 5: 6170.

19. Arie Jan van Winkelhoff (2012) Antibiotics in the treatment of peri-implantitis. Eur J Oral Implantol 5: 43-50.

20. Leonhardt A, Dahlén G, Renvert S (2003) Five-year clinical, microbiological, and radiological outcome following treatment of peri-implantitis in man. J Periodontol 74: 1415-1422.

21. Chan HL, Lin GH, Suarez F, MacEachern M, Wang HL (2014) Surgical management of peri-implantitis: a systematic review and meta-analysis of treatment outcomes. J Periodontol 85: 1027-1041.

22. Nevins, Mellonig. Periodontal therapy: clinical approaches and evidence of success-iberlibro.com.

23. Romanos GE, Nentwig GH (2008) Regenerative Therapy of Deep Peri-implant Infrabony Defects After CO2 Laser Implant Surface Decontamination. Int J Periodontics Restorative Dent 28: 244255.

24. Schwarz F, Sahm N, Becker J (2014) Combined surgical therapy of advanced peri-implantitis lesions with concomitant soft tissue volume augmentation. A case series. Clin Oral Implants Res 25: 132-136.

25. Schwarz F, Sahm N, Schwarz K, Becker J (2014) Impact of defect configuration on the clinical outcome following surgical regenerative therapy of peri-implantitis. J Clin Periodontol 37: 449-455. 
26. Froum SJ, Froum SH, Rosen PS (2012) Successful Management of Peri-Implantitis with a Regenerative Approach: A Consecutive Series of 51 Treated Implants with 3- to 7.5-Year Follow-up. Int J Periodontics Restorative Dent 32: 11-20.

27. Haas R, Baron M, Dörtbudak O, Watzek G (2000) Lethal Photosensitization, Autogenous Bone, and e-PTFE Membrane for the Treatment of Peri-implantitis: Preliminary Results. Int J Oral Maxillofac Implants 15: 374-382.

28. Matarasso S, lorio Siciliano V, Aglietta M, Andreuccetti G, Salvi GE (2014) Clinical and radiographic outcomes of a combined resective and regenerative approach in the treatment of periimplantitis: a prospective case series. Clin Oral Implants Res 25: 761-767.

29. Máximo MB, de Mendonça AC, Renata Santos V, Figueiredo LC, Feres $M$, et al. (2009) Short-term clinical and microbiological evaluations of peri-implant diseases before and after mechanical anti-infective therapies. Clin Oral Implants Res 20: 99-108.

30. Mijiritsky E, Yatzkaier G, Mazor Z, Lorean A, Levin L (2013) The use of porous titanium granules for treatment of peri-implantitis lesions: preliminary clinical and radiographic results in humans. Br Dent J 214.

31. Roccuzzo M, Bonino F, Bonino L, Dalmasso P (2011) Surgical therapy of peri-implantitis lesions by means of a bovine-derived xenograft: comparative results of a prospective study on two different implant surfaces: Surgical treatment of peri-implantitis. J Clin Periodontol 38: 738-745.

32. Roos-Jansaker A-M, Renvert H, Lindahl C, Renvert S (2007) Submerged healing following surgical treatment of periimplantitis: a case series. J Clin Periodontol 34: 723-727.

33. Schwarz F, Sahm N, Bieling K, Becker J (2009) Surgical regenerative treatment of peri-implantitis lesions using a nanocrystalline hydroxyapatite or a natural bone mineral in combination with a collagen membrane: a four-year clinical follow-up report. J Clin Periodontol 36: 807-814.

34. Wiltfang J, Zernial O, Behrens E, Schlegel A, Warnke PH, et al. (2012) Regenerative Treatment of Peri-Implantitis Bone Defects with a Combination of Autologous Bone and a Demineralized Xenogenic Bone Graft: A Series of 36 Defects: Regenerative Treatment of Peri-Implantitis Bone Defects. Clin Implant Dent Relat Res 14: 421-427.
35. Romeo E, Ghisolfi M, Murgolo N, Chiapasco M, Lops D, et al. (2004) Therapy of peri-implantitis with resective surgery: A 3-year clinical trial on rough screw-shaped oral implants. Part I: clinical outcome. Clin Oral Implants Res 16: 9-18.

36. Wohlfahrt JC, Lyngstadaas SP, Rønold HJ, Saxegaard E, Ellingsen $\mathrm{JE}$, et al. (2012) Porous Titanium Granules in the Surgical Treatment of Peri-Implant Osseous Defects: A Randomized Clinical Trial. Int J Oral Maxillofac Implants 27: 401-410.

37. Schwarz F, John G, Mainusch S, Sahm N, Becker J (2012) Combined surgical therapy of peri-implantitis evaluating two methods of surface debridement and decontamination. A twoyear clinical follow up report. J Clin Periodontol 39: 789-797.

38. Aghazadeh A, Rutger Persson G, Renvert S (2012) A single-centre randomized controlled clinical trial on the adjunct treatment of intra-bony defects with autogenous bone or a xenograft: results after 12 months. J Clin Periodontol 39: 666-673.

39. de Waal YCM, Raghoebar GM, Huddleston Slater JJR, Meijer HJA, Winkel EG, et al. (2013) Implant decontamination during surgical peri-implantitis treatment: a randomized, double-blind, placebo-controlled trial. J Clin Periodontol 40: 186-195.

40. Khoury $F$ (2001) Surgical Therapy of Peri-Implant Disease: A 3-Year Follow-Up Study of Cases Treated With 3 Different Techniques of Bone. J Periodontol 72: 1498-1508.

41. Deppe H, Horch HH, Neff A (2007) Conventional Versus CO2 Laser-Assisted Treatment of Pen-implant Defects with the Concomitant Use of Pure-Phase $\beta$-Tricalcium Phosphate: A 5-year Clinical Report. Int J Oral Maxillofac Implants 22: 79-86.

42. Roos-Jansaker AM, Lindahl C, Persson GR, Renvert S (2011) Long-term stability of surgical bone regenerative procedures of peri-implantitis lesions in a prospective case-control study over 3 years: Surgical treatment of peri-implantitis. J Clin Periodontol 38: $590-597$.

43. Roos-Jansaker AM, Persson GR, Lindahl C, Renvert S (2014) Surgical treatment of peri-implantitis using a bone substitute with or without a resorbable membrane: a 5-year follow-up. J Clin Periodontol 41: 1108-1114.

44. Heitz-Mayfield LJA, Salvi GE, Mombelli A, Faddy M, Lang NP, et al. (2012) Anti-infective surgical therapy of peri-implantitis. A 12-month prospective clinical study. Clin Oral Implants Res 23: 205-210. 